Retraction

\title{
Retracted: The Studies of Chlorogenic Acid Antitumor Mechanism by Gene Chip Detection: The Immune Pathway Gene Expression
}

\author{
Journal of Analytical Methods in Chemistry
}

Received 10 November 2020; Accepted 10 November 2020; Published 21 December 2020

Copyright (c) 2020 Journal of Analytical Methods in Chemistry. This is an open access article distributed under the Creative Commons Attribution License, which permits unrestricted use, distribution, and reproduction in any medium, provided the original work is properly cited.

Journal of Analytical Methods in Chemistry has retracted the article titled "The Studies of Chlorogenic Acid Antitumor Mechanism by Gene Chip Detection: The Immune Pathway Gene Exdmpression" [1]. Confidential information from Sichuan Jiuzhang Biological Science \& Technology Co., Ltd. (previously known as Sichuan Jiuzhang Biochemical Engineering Science and Technology Development Co., Ltd.) was published without permission, as confirmed by a court judgment. A previous corrigendum that acknowledged the involvement of the company was not sufficient [2].

\section{References}

[1] T. Y. Kang, H. R. Yang, J. Zhang et al., "The Studies of Chlorogenic Acid Antitumor Mechanism by Gene Chip Detection: The Immune Pathway Gene Expression," Journal of Analytical Methods in Chemistry, vol. 2013, Article ID 617243, 7 pages, 2013.

[2] T. Y. Kang, H. R. Yang, J. Zhang et al., "Corrigendum to "The Studies of Chlorogenic Acid Antitumor Mechanism by Gene Chip Detection: The Immune Pathway Gene Expression"," Journal of Analytical Methods in Chemistry, vol. 2015, Article ID 538539, 1 page, 2015. 